\title{
Pengaruh Kualitas Kehidupan Kerja Terhadap Kinerja Karyawan Dengan Kepuasan Kerja Sebagai Variabel Intervening
}

\author{
Achmad Agus Priyono ${ }^{1}$ \\ ${ }^{1}$ Fakultas Ekonomi Universitas Islam Malang, Indonesia \\ Email:aapuim@unisma.ac.id
}

Submitted: $14-01-2020$

Revised : 11-03-2020

Accepted: 15-04-2020

\begin{abstract}
Abstrak: The purpose of this study was to determine the effect of the variable Quality of Work Life on Employee Performance with Job Satisfaction as an intervening variable. The data in this study are primary data obtained by giving questionnaires to employees of the T.U.K PG section. Malang Grand Garden. Data analysis used is linear regression and path analysis. The results of data analysis showed that 1) there was a positive and significant influence between the quality of work life $(\mathrm{X})$ on employee performance $(\mathrm{Y})$., 2) there was a positive and significant influence between the variables of the quality of work life $(\mathrm{X})$ on job satisfaction $(\mathrm{Z}), 3$ ) there is a positive and significant effect between the variables Job Satisfaction $(\mathrm{Z})$ on Employee Performance $(\mathrm{Y})$ and 4) Job Satisfaction $(\mathrm{Z})$ mediates the relationship between the quality of work life $(\mathrm{X})$ on Employee Performance $(\mathrm{Y})$.
\end{abstract}

Keywords: Quality of work life, job satisfaction, and employee performance

https://doi.org/10.54069/attadrib.v3i1.111

How to Cite Priyono.A.A (2021). Pengaruh Kualitas Kehidupan Kerja Terhadap Kinerja Karyawan Dengan Kepuasan Kerja Sebagai Variabel Intervening. Attadrib: Jurnal Pendidikan Guru Madrasab Ibtidaiyah, 3 (1) 31-42

\section{PENDAHULUAN}

Sumber daya manusia merupakan salah satu asset yang sangat berharga, untuk itulah perusahaan bertanggungjawab untuk senantiasa mengembangkan dan menjaga kualitas kehidupan kerja serta memotivasi sumber daya manusianya sehingga dapat memberikan kontribusinya dalam kerangka pencapaian tujuan perusahaan. Untuk itulah perusahaan harus mendorong terciptanya perasaan aman dari para karyawan dan kepuasan dalam bekerja sehingga dapat turut mewujudkan tujuan perusahaan (Hadari, 2008).

Lebih lanjut (Cascio, 2010) menyatakan bahwa untuk menciptakan kualitas kehidupan kerja perusahaan harus membuat sebuah kebijakan yang dapat membuat kondisi kerja yang aman, melibatkan karyawan dalam setiap rancangan pekerjaan, kebijakan terkait dengan pengembangan karir, kebijakan tentang pengajian yang adil dan lain sebagainya. Dengan demikian setiap usaha dalam peningkatan kualitas kehidupan kerja karyawan akan dapat memberikan positive feeling yang meluas, sehingga pada akhirnya dapat berdampak terhadap peningkatan kinerja karyawan.

Selain pengingkatan kualitas kehidupan kerja, perusahan juga harus memperhatikan kepuasan kerja. Hasibuan, (2013) menjelaskan bahwa kepuasan kerja mengambarkan perasaan puas di dalam bekerja yang dinikmati oleh karyawan didalam pekerjaannya dengan mendapatkan pujian terhadap hasil kinerjanya, penempatan sesuai dengan bidangnya, perlakuan yang baik, penyediaan peralatan kerja, serta adanya suasana lingkungan kerja yang baik. Dengan demikian 
karyawan akan merasa nyaman dalam lingkungan dan memiliki kualitas kehidupan kerja yang baik sehingga dapat melaksanakan pekerjaanya dengan baik sesuai dengan tujuan dari perusahaan.

Dengan perbaikan perusahaan terhadap kualitas kehidupan kerja dan kepuasan kerja yang baik, diharapkan karyawan dapat meningkatkan kinerjanya. Upaya peningkatan kinerja serta keterlibatan karyawan dalam setiap proses pengambilan keputusan dan pemenuhan kebutuhan dari karyawan merupakan aplikasi dari kualitas kehidupan kerja. Perusahaan hendaknya memiliki kreasi dan inovasi dalam menjawab berbagai tantangan manajemen dengan menciptakan kualitas kehidupan kerja yang sesuai, sehingga karyawan dalam bekerja dapa meraih kepuasan serta terciptanya disiplin kerja yang tinggi.

Kualitas kehidupan kerja merupakan aktifitas dalam perusahaan yang ditujukan untuk meningkatakan kondisi lingkungan kerja yang dapat meningkatkan semangat dan gairah kerja sehingga tujuan perusahaan dapat tercapai (Cascio, 2010). Perusahaan harus secara terus menerus menumbuh kembangkan semangat dan gairah kerja tersebut, sehingga terciptanya budaya kerja yang tinggi bagi para karyawan. Perilaku dari karyawan terhadap pemenuhan kebutuhan serta keinginan terhadap diri sendiri akan memberikan respon positif kinerja perusahaan. Dengan demikian, perusahaan yang berkualitas merupakan perusahaan yang memiliki kualitas hidup kerja yang baik, yang dapat meningkatkan kesejahteraan karyawan serta dapat mewujukan karyawan yang berdaya saing dan berkompetensi.

Berdasarkan latar belakang tersebut, maka kualitas kehidupan kerja, kepuasan kerja dan kinerja karyawan pada karyawan bagian T.U.K PG. Kebon Agung Malang menjadi topik penelitian ini. Hasil penelitian ini diharapkan dapat dijadikan bahan pertimbangan perusahaan dalam menciptakan QWL (kualitas kehidupan kerja), kepuasan kerja yang berdampak pada peningkatan kinerja karyawan pada karyawan bagian T.U.K PG. Kebon Agung Malang.

\section{KAJIAN TEORI}

\section{Kinerja}

Dessler, (2006), menyatakan bahwa kinerja pegawai adalah prestasi kerja, dimana merupakan perbandingan antara hasil kerja yang diperoleh secara nyata dibandingkan dengan standar kerja yang ditetapkan organisasi. Sementara itu Timpe, (2002) menyatakan bahwa kinerja merupakan sebuah aksi dari karyawan, jadi bukan merupakan kejadian. Sedangkan (Mankunegara, 2002) menyatakan kinerja adalah sesuatu yang dicapai karyawan.

Kinerja karyawan pada hakekatnya dikendalikan oleh masing-masing karyawan, dengan demikian kinerja merupakan capaian yang dapat dicapai oleh karyawan tersbut didalam menjalankan tugas sesuai dengan tanggung jawab yang diembannya. Lebih lanjut Bernadin \& Russel, (2003) menyatakan bahwa untuk mengevaluasi kinerja karyawan terdapat 6 (enam) dimensi, yaitu : a) Quality, dimana merupakan ukuran dari proses atau hasil dari optimalisasi pekerjaan yang telah menjadi standarisasi pekerjaan tersebut, b) Quantity, merupakan output yang dihasilkan oleh karyawan yang dinyatakan dalam satuan mata uang, jumlah unit, yang mampu diselesaikannya. c) Timelinnes, merupakan standarisasi waktu penyelesaian yang dapat dikerjakan oleh karyawan dalam menyelesaikan pekerjaan tersebut, d) Cost effectivennes, merupakan penggunaan sumber daya baik sumber daya manusia, keuangan, teknologi, dan bahan baku yang dapat di minimalisasi karyawan dalam menyelesaiakan pekerjaan tersebut, e) Need for Supervision, merupakan kemampuan karyawan dalam menyelesaikan pekerjaan tanpa adanya pengawasan serta sesuai dengan standar yang telah ditetapkan perusahaan, f) Interpersonal Impact, merupakan kemampuan karyawan didalam mengembangkan perasaan saling menghargai, niat baik, dan kerjasama antara karyawan yang satu dengan yang lain, dan juga pada bawahan.

\section{Kualitas Kehidupan kerja}

Kualitas Kehidupan kerja (Quality of Work Life) memiliki peranan yang sangat penting didalam meningkatkan kinerja karyawan (Mousavi et al., 2011). Walton RE, (1973) menjelaskan bahwa kualitas kehidupan kerja merupakan pandangan karyawan terhadap kondisi serta pengalaman dari karyawan ditempat kerja mereka bekerja. Sedangkan Cascio, (2010) menyatakan 
bahwa kualitas kehidupan kerja adalah memberi para karyawan kesempatan guna mengambil keputusan terkait pekerjaan, desain tempat kerja, serta apa dibutuhkan para karyawan untuk menciptkana sebuah produk ataupun jasa secara efektif.

Terdapat empat (4) indikator dalam kualitas kehidupan kerja menurut Walton RE, (1973) yaitu : a) Pertumbuhan dan pengembangan, dimana perusahaan memberikan kemungkinan dan kesempatan kepada para karyawan untuk mengembangkan kemampuan serta mempergunakan kemampuan dan ketrampilannya, b) Partisipasi, dimana perusahaan memberikan kesempatan kepada para karyawan untuk berpartisipasi aktif didalam pengambilan keputusan yang memiliki implikasi baik secara langsung atau tidak langsung terhadap pekerjaannya, c) Sistem imbalan yang diberikan bersifat inovatif, dimana perusahaan didalam memberikan imbalan kepada karyawan dapat mencukupi kehidupan karyawan dan berdasarkan standard hidup pada daerah dimana karyawan tersebut bekerja (upah minimum regional), d) Lingkungan pekerjaan, dimana lingkungan kerja bersifat kondusif, serta terdapat suatu tata tertib yang jelas.

\section{Kepuasan Kerja}

Robbins, (2008) menjelaskan bahwa kepuasan kerja merupakan sikap umum karyawan terhadap yang telah dilakukannya senang, puas atau tidak puas didalam pekerjaannya. Seorang karyawan dengan tingkat kepuasan kerja yang tinggi menunjukan adanya sikap yang positif terhadap kerja tersebut, lain halnya dengan seorang karyawan yang tidak puas terhadap pekerjaannya akan menunjukan sikap negatif terhadap pekerjaannya tersebut.

Smith, dalam Robbins, (2008) menjelaskan terdapat 5 dimensi yang berpengaruh terhadap respon afektif seseorang karyawan terhadap pekerjaannya, diantaranya a) Pekerjaan, dimana pekerjaanya tersebut memberikan kesempatan pada karyawan guna belajar untuk mendapatkan tanggung jawab dalam pekerjaan tersebut serta mendapatkan tantangan dari pekerjaan tersebut. b) Upah, dimana upah yang didapatkan oleh karyawan sebanding dengan usaha yang telah dilakukannya serta setara dengan upah yang diterima oleh karyawan lain dalam posisi kerja yang sederajat. c) Kesempatan dalam promosi, merupakah kesempatan yang didapat karyawan guna meraih kesempatan atau dipromosikan ke dalam jenjang yang lebih tinggi. d) Atasan, dimana atasan memiliki kemampuan untuk membimbing dan memotivasi para karyawan yang menjadi bawahannya. 5) Kolega, kolega yang baik adalah kolega yang saling mendukung didalam pekerjaan baik dukungan yang bersifat moral maupun dukungan yang bersifat teknis sesama kolega dalam menyelesaikan pekerjaan.

\section{HUBUNGAN ANTAR VARIABEL DAN PENGEMBANGAN HIPOTESIS}

Perusahaan yang tidak memperhatikan faktor kualitas kehidupan kerja dari para pekerjanya akan berakibat merosotnya tingkat kinerja karyawannnya. Karena kualitas kehidupan kerja merupakan salah satu tujuan yang ingin dicapai karyawan dalam pemenuhan kebutuhan serta keinginannya. Hal tersebut sesuai dengan hasil penelitian yang dilakukan oleh Hadiwijaya, (2016), Wibowo, (2017), Husnawati, (2006), Sudiq, (2020) dan Kurniawati, (2018) yang didalam hasil penelitiannya menemukan bahwa kualitas kehidupan kerja dapat meningkatkan kinerja karyawan. Berdasarkan kajian teori serta hasil peneliti terdahulu tersebut, hipotesis yang diajukan peneliti :

H1 : Terdapat pengaruh positif dan siginifikan antara variabel kualitas kehidupan kerja $(\mathrm{X})$ terhadap kinerja karyawan $(\mathrm{Y})$.

Sebagaimana dijelaskan oleh Handoko, (2012); dan Robbins, (2008) bahwa Kepuasan kerja merupakan suatu keadaan emosional dari karyawan yang menyenangkan atau tidak menyenangkan. Kepuasan kerja mencerminkan perasaan karyawan terhadap pekerjaan yang diembannya, hal ini ditunjukkan oleh karyawan pada sikap positif pada pekerjaannya dan juga terhadap segala sesuatu dalam lingkungan kerjanya. Sehingga untuk mewujudkan kepuasan kerja perusahaan harus memperhatikan tingkat kualitas kehidupan kerjanya. Hal tersebut sejalan dengan penelitian yang dilakukan oleh Normala, (2010), Husnawati, (2006), Bekti, (2018), dan Sudiq, (2020) yang didalam hasil penelitiannya menemukan bahwa penerapan Kualitas Kehidupan 
Kerja dapat meningkatkan kepuasan kerja karyawan di perusahaan. Berdasarkan kajian teori serta hasil peneliti terdahulu tersebut, hipotesis yang diajukan peneliti :

H2 : Terdapat pengaruh positif dan siginifikan antara variabel kualitas kehidupan kerja (X) terhadap kepuasan Kerja (Z).

Bilamana seseorang karyawan memiliki tingkat kepuasan kerja yang tinggi maka akan berdampak pada sikap positif terhadap pekerjaan yang diembannya, sebaliknya bilamana karyawan tersebut tidak memiliki kepuasan kerja maka akan sikap negatif akan ditunjukkan terhadap pekerjaan yang diembannya. Hal tersebut sejalan dengan penelitian yang dilakukan oleh Husnawati, (2006), Lusri, (2017) dan (Tobing, 2009) yang menemukan bahwa kepuasan kerja dapat meningkatkan kinerja karyawan. Berdasarkan kajian teori serta hasil peneliti terdahulu tersebut, hipotesis yang diajukan peneliti :

H3 : Terdapat pengaruh positif dan siginifikan antara variabel Kepuasan Kerja (Z) terhadap Kinerja Karyawan (Y).

Husnawati, (2006) dalam penelitian menemukan bahwa kepuasan kerja memediasi pengaruh tidak langsung antara kualitas kehidupan kerja terhadap kinerja karyawan pada Perum Pegadian Kanwil VI Semarang. Berdasarkan kajian teori serta hasil peneliti terdahulu tersebut, hipotesis yang diajukan peneliti :

H4 : Kualitas kehidupan kerja $(X)$ berpengaruh signifikan positif terhadap Kinerja Karyawan $(\mathrm{Y})$ melalui kepuasan kerja $(\mathrm{Z})$ sebagai variabel intervening

\section{METODE PENELITIAN}

Penelitian ini dilakukan pada PG. Kebon Agung Malang. Pada penelitian ini dipergunakan pendekatan kuantitatif dengan variabel independent Kualitas kehidupan kerja (X), dan variable dependen Kinerja Karyawan (Y) serta variabel intervening kepuasan kerja (Z). Adapun data dalam penelitian ini merupakan data primer yang diperoleh secara langsung melalui penyebaran kuisioner. Kuisioner tersebut diberikan langsung kepada pegawai Rumah Sakit Ibu dan Anak Puri Galeri Malang. Pengujian data pada penelitian ini dipergunakan analisis regresi linier dengan mempergunakan SPSS.

Sugiyono, (2012) menjelaskan bahwa populasi merupakan wilayah generalisasi yang meliputi subyek yang memiliki kualitas serta karakteristik tertentu yang telah ditetapkan peneliti guna dipelajari dan pada akhirnya diambil sebuah kesimpulan. Berdasarkan penjelasan tersebut, yang menjadi populasi pada penelitian ini adalah karyawan dari PG. Kebon Agung Malang. Adapun sampel yang dipegunakan adalah karyawan bagian T.U.K PG. Kebon Agung Malang yang berjumlah 60 orang karyawan.

\section{Analisis Regresi}

Adapun model persamaan regresi linear adalah sebagai berikut :

$$
\begin{array}{lll}
\text { Persamaan I } & : & \mathrm{Y}=\mathrm{a} 1+\mathrm{a} 2 \mathrm{X}+\mathrm{ei} \\
\text { Persamaan II } & : & \mathrm{Z}=\mathrm{a} 3+\mathrm{a} 4 \mathrm{X}+\mathrm{ei} \\
\text { Persamaan III } & : & \mathrm{Y}=\mathrm{a} 5+\mathrm{a} 6 \mathrm{X}+\mathrm{a} 7 \mathrm{Z}+\mathrm{ei}
\end{array}
$$

\section{Dimana :}

$\begin{array}{lll}\mathrm{Y}= & \text { Kinerja Karyawan } \\ \mathrm{X}= & \text { Quality of Work Life } \\ \mathrm{Z}= & \text { Kepuasan Kerja } \\ \mathrm{a} 1, \mathrm{a} 3, \mathrm{a} 5 & = & \text { Konstanta } \\ \mathrm{a} 2, \mathrm{a} 4, \mathrm{a} 6, \mathrm{a} 7 & = & \text { Koefisien Regresi } \\ \mathrm{ei} \quad= & \text { Standart error }\end{array}$

Analisis Jalur (Path Analysis)

Untuk menguji pengaruh variabel intervening digunakan metode analisis jalur (Path Analysis). Analisis jalur merupakan pengembangan dari analisis regresi linier berganda, atau analisis jalur adalah aplikasi dari analisis regresi yang berfungsi untuk menaksir hubungan 
kausalitas antar variabel (model casual) yang telah ditetapkan sebelumnya berdasarkan teori (Ghozali, 2011:249).

Berikut ini gambar analisis jalur untuk menguji hubungan antara variabel Kualitas Kehidupan Kerja (X) terhadap kinerja karyawan (Y) dan apakah hubungan Kualitas Kehidupan Kerja $(\mathrm{X})$ terhadap kinerja karyawan $(\mathrm{Y})$ dimediasi oleh variabel Kepuasan Kerja $(\mathrm{Z})$ :

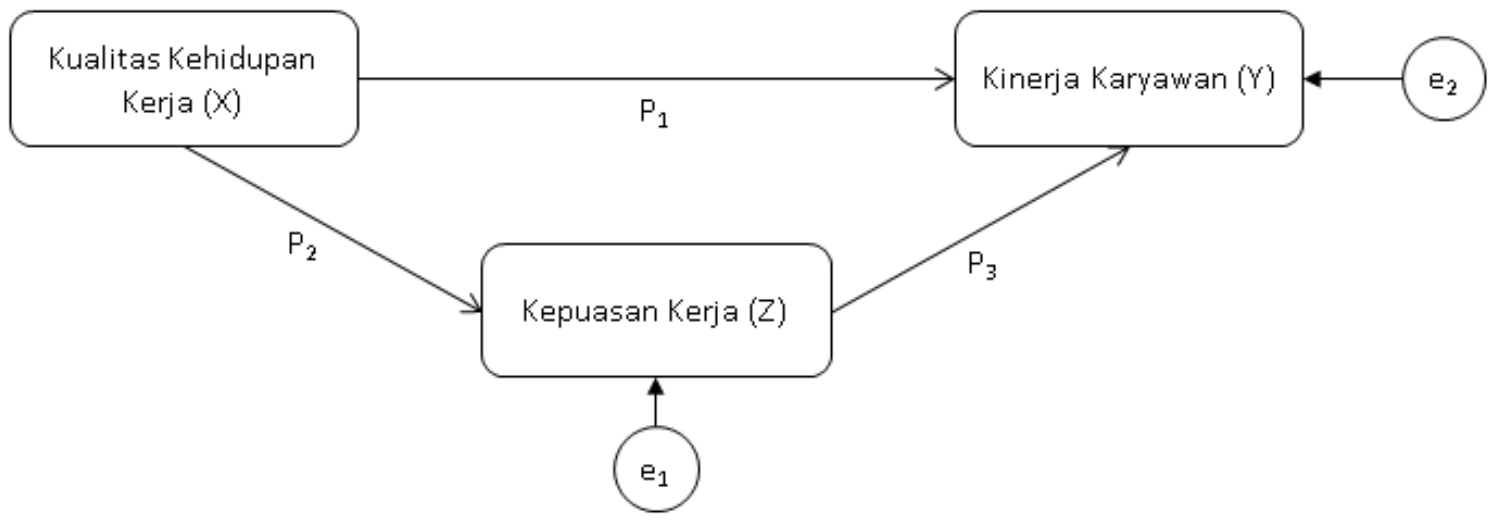

Gambar 2 : Model Path Analysis

Berdasarkan gambar model Path Analysis diajukan hubungan berdasarkan teori bahwa Kualitas Kehidupan Kerja (X) memiliki hubungan langsung terhadap Kinerja Karyawan (Y) = P1 dan Kualitas Kehidupan Kerja (X) terhadap Kepuasan Kerja $(Z)=$ P2. Sementara itu untuk hubungan tidak langsung antar Kualitas Kehidupan Kerja (X) terhadap Kinerja Karyawan (Y) melalui Kepuasan Kerja $(Z)=$ P3. Sehingga total pengaruh hubungan dari Kualitas Kehidupan Kerja $(\mathrm{X})$ terhadap Kinerja Karyawan $(\mathrm{Y})$ diperoleh :

Pengaruh langsung $\quad=\quad \mathrm{P} 1$

Pengaruh tidak langsung $=\quad \mathrm{P} 2 \times \mathrm{P} 3$

Pengaruh total $=\mathrm{P} 1+(\mathrm{P} 2 \times \mathrm{P} 3)$

Koefisien e1 menunjukkan jumlah variance variabel Kepuasan Kerja ( $Z$ ) yang tidak

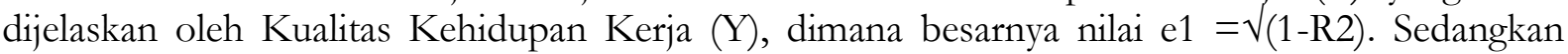
koefisien e2 menunjukkan variance kinerja karyawan yang tidak dapat dijelaskan oleh variabel Kualitas Kehidupan Kerja (Y) dan Kepuasan Kerja (Z), Dimana besarnya nilai e2 $=\sqrt{ }(1-R 2)$.

Ghozali, (2011) menjelaskan bahwa untuk mengevaluasi ada tidaknya pengaruh mediasi yang ditunjukkan perkalian koefisien (P2 x P3), berpengaruh signifikan atau tidak, ditunjukkan nilai standar error dari koefisien indirect effect $(\mathrm{sp} 2 \mathrm{p} 3)$. Adapun formulasinya sebagai berikut :

$\mathrm{S} \_\mathrm{P} 2 \mathrm{P} 3=\sqrt{ }\left(\left[\mathrm{P} \_3 \rrbracket^{\wedge} 2 .\left[\mathrm{S} \_\mathrm{P} 2 \rrbracket^{\wedge} 2+\llbracket \mathrm{P} \_2 \rrbracket^{\wedge} 2 .\left[\mathrm{S} \_\mathrm{P} 3 \rrbracket^{\wedge} 2+\llbracket \mathrm{S} \_\mathrm{P} 2 \rrbracket^{\wedge} 2 \llbracket \mathrm{S} \_\mathrm{P} 3 \rrbracket^{\wedge} 2\right)\right.\right.\right.$

Dimana :

Sp2p3 = Koefisien indirect effect

$\mathrm{p}=$ jalur $\mathrm{p}$

Sp $\quad=$ standar error

Berdasarkan Sp2p3 ini, dapat dihitung nilai $\mathrm{t}$ statistik pengaruh mediasi dengan rumus $\mathrm{t}$ hitung $=\mathrm{p} 2 \mathrm{p} 3 / \mathrm{Sp} 2 \mathrm{p} 3$. Bila nilai $\mathrm{t}$ hitung $>$ dari $\mathrm{t}$ tabel dengan tingkat signifikansi 0,05 , maka dapat disimpulkan bahwa koefisien mediasi signifikan yang berarti ada pengaruh mediasi.

\section{HASIL}

\section{Uji Instrumen}

Ghozali, (2011) menjelaskan bahwa uji validitas dipergunakan untuk mengukur sah, atau valid tidaknya suatu kuesioner. Item pertanyaan didalam kuesioner dinyatakan valid, bilamana didalam item pertanyaan tersebut mampu mengungkapkan sesuatu yang akan diukur oleh 
kuesioner tersebut. Pada penelitian ini, uji validitas dilakukan dengan melakukan korelasi bivariate antara masing-masing skor indikator dengan total skor konstruk. Nilai r-hitung dari masing-masing item pertanyaan diperoleh nilai lebih besar dari rtabel $(0,259)$. Berdasarkan hasil analisis tersebut, masing-masing memiliki nilai $\mathrm{r}$ hitung $>\mathrm{r}$ tabel dapat disimpulkan bahwa pertanyaan pada kuesioner tersebut valid.

Setelah item pertanyaan terbukti valid, langkah berikutnya adalah menguji reabilitas dari item pertanyaan tersebut. (Ghozali, 2011) menjelaskan bahwa suatu item pertanyaan didalam kuesioner dinyatakan reliabel atau handal adalah bilamana jawaban responden terhadap pertanyaan atau pernyataan dalam kuesioner tersebut adalah konsisten atau stabil dari waktu ke waktunay. Suatu konstruk dinyatakan reliabel bilamana nilai Cronbach Alpha $>0,70$. Berdasarkan hasil analisis diperoleh nilai Cronbach Alpha lebih besar dari nilai kritis 0,70. Dengan demikian dapat disimpulkan pertanyaan yang digunakan dalam kuesioner penelitian ini sudah reliabel atau dapat dihandalkan.

\section{Uji Normalitas}

Untuk mengetahui distribusi dari sebaran data yang diperoleh, apakah berdistribusi normal atau tidak maka dipergunakan uji normalitas (Ghozali, 2011). Hasil uji normalitas dipergunakan metode One-Sampel Kolmogorov- Smirnov Test menunjukkan nilai signifikansi (probabilitas) masing-masing variabel sebesar 0,341 untuk variabel Kualitas Kehidupan Kerja (X), 0,985 untuk variabel Kepuasan Kerja (Z) dan 0,482 untuk variabel Kinerja Karyawan (Y). Dengan demikian distribusi data dari seluruh variabel yang digunakan dalam penelitian ini berdistribusi normal karena nilai asymp. Sig (2-tailed) dari Kolmogorov-Smirnov Z masingmasing lebih besar dari 0,05.

\section{Uji Heterokedastisitas}

Uji heteroskedastisitas dalam penelitian ini dipergunakan uji Park (Park Test) yaitu dengan cara meregresikan Ln dari residual terhadap Ln dari Variabel Independen, dimana tingkat signifikansi dari hasil regresi antara $\ln X, \ln Z$, terhadap Lnei2 (logaritma natural dari residual yang dikuadratkan) secara sendiri-sendiri harus lebih kecil dari nilai t-tabel. Berdasarkan hasil analisis dapat diketahui bahwa model regresi dalam penelitian ini menunjukkan tidak mengalami masalah heteroskedastisitas karena tuji dari masing-masing variabel lebih besar dari t-tabel sebesar 2,002 $(\mathrm{df}=60-2=58, \square=0,05)$.

\section{Uji Multikolinieritas}

Uji multikolinieritas dipergunakan untuk mendeteksi apakah diantara variabel independent saling berkorelasi atau tidak. Untuk mendeteksi masalah multikolinieritas pada penelitian ini dipergunakan kajian terhadap nilai Variance Inflation Faktor (VIF). Nilai VIF dari masing-masing variabel diperoleh nilai lebih kecil dari 10. Sehingga dapat disimpulkan bahwa pada persamaan model regresi tidak mengandung masalah multikolinieritas.

Analisis Regresi

Hasil analisis regresi linear dari masing-masing persamaan dengan mempergunakan program SPSS sebagai berikut:

Persamaan I : Y $=\mathrm{a} 1+\mathrm{a} 2 \mathrm{X}+\mathrm{ei}$

Tabel 1 : Hasil Analisis Regresi Linier Sederhana antara Kualitas Kehidupan Kerja (X) terhadap Kinerja Karyawan (Y)

Coefficients(a)

\begin{tabular}{|c|c|c|c|c|c|c|}
\hline \multirow[b]{2}{*}{ odel } & & \multicolumn{2}{|c|}{$\begin{array}{l}\text { Unstandardized } \\
\text { Coefficients }\end{array}$} & \multirow{2}{*}{$\begin{array}{c}\begin{array}{c}\text { Standard } \\
\text { ized } \\
\text { Coefficients }\end{array} \\
\text { Beta }\end{array}$} & \multirow[b]{2}{*}{$\mathrm{t}$} & \multirow[b]{2}{*}{ Sig. } \\
\hline & & B & $\begin{array}{l}\text { Std. } \\
\text { Error }\end{array}$ & & & \\
\hline 1 & (Constant) & ,465 & ,572 & & ,813 &, 420 \\
\hline & $\begin{array}{c}\text { Kualitas } \\
\text { Kehidupan Kerja }(\mathrm{X})\end{array}$ & ,881 & 163, & ,578 & $\begin{array}{r}5,39 \\
1\end{array}$ & ,000 \\
\hline
\end{tabular}


a Dependent Variable: Kinerja Karyawan (Y)

Sumber : Data diolah

Berdasarkan tabel tersebut persamaan regresi linier sederhana disusun, sebagai berikut : $\mathrm{Y}=0,465$ $+0,881 \mathrm{X}+\mathrm{ei}$

Makna persamaan regresi linier sederhana sebagai berikut :

1. Konstanta sebesar 0,465 menunjukkan tanpa variabel Kualitas Kehidupan Kerja (X), maka nilai variabel kinerja karyawan $(\mathrm{Y})$ adalah sebesar 0,465 .

2. Koefisien regresi variabel Kualitas Kehidupan Kerja (X) sebesar 0,881 menunjukkan bahwa setiap perubahan Kualitas Kehidupan Kerja (X) sebesar satu satuan maka akan mengakibatkan peningkatan kinerja karyawan (Y) sebesar 0,578, dengan asumsi variabel lainnya adalah konstan (tetap).

Sedangkan untuk mengetahui seberapa besar pengaruh variabel Kualitas Kehidupan Kerja (X) terhadap Kinerja Karyawan (Y), dapat dilihat hasil analisis Koefisien Determinasi (R2) dengan hasil sebagai berikut :

Tabel 2: Hasil Pengujian Koefisien Determinasi Kualitas Kehidupan Kerja (X) terhadap Kinerja Karyawan (Y)

Model Summary

\begin{tabular}{|c|c|c|c|c|}
\hline $\begin{array}{ll} & \text { Mo } \\
\text { del } & \end{array}$ & $\mathrm{R}$ & $\begin{array}{c}\mathrm{R} \\
\text { Square }\end{array}$ & Adjusted R Square & Std. Error of the Estimate \\
\hline 1 &, $578^{a}$ &, 334 & ,332 & ,679346 \\
\hline
\end{tabular}

a Predictors: (Constant), Kualitas Kehidupan Kerja (X)

Berdasarkan tabel 2 tersebut diperoleh nilai Adjusted R Square $\left(\mathrm{R}^{2}\right)$ sebesar 0,334 artinya 33,4\% variasi kinerja karyawan $(\mathrm{Y})$ dipengaruhi Kualitas Kehidupan Kerja $(\mathrm{X})$, sisanya 66,6\% dipengaruhi oleh variabel lainnya yang tidak masuk dalam model ini.

Persamaan II : $\quad Z=a_{3}+a_{4} X+e_{i}$

Tabel 3 : Hasil Analisis Regresi Linier Sederhana antara Kualitas Kehidupan Kerja (X) terhadap Kepuasan Kerja (Y)

\begin{tabular}{|c|c|c|c|c|c|c|}
\hline \multicolumn{7}{|c|}{ Coefficients(a) } \\
\hline \multirow[b]{2}{*}{ odel } & & \multicolumn{2}{|c|}{$\begin{array}{l}\text { Unstandardized } \\
\text { Coefficients }\end{array}$} & \multirow{2}{*}{$\begin{array}{c}\begin{array}{c}\text { Standardiz } \\
\text { ed Coefficients }\end{array} \\
\text { Beta }\end{array}$} & \multirow[b]{2}{*}{$\mathrm{t}$} & \multirow[b]{2}{*}{ Sig. } \\
\hline & & B & $\begin{array}{l}\text { Std. } \\
\text { Error }\end{array}$ & & & \\
\hline \multirow[t]{2}{*}{1} & (Constant) & 2,412 &, 472 & & 5,109 &, 000 \\
\hline & $\begin{array}{c}\text { Kualitas } \\
\text { Kehidupan Kerja (X) }\end{array}$ & ,403 & ,135 &, 365 & 2,990 & ,004 \\
\hline
\end{tabular}

a Dependent Variable: Kepuasan Kerja (Z)

Sumber : Data diolah

Berdasarkan tabel tersebut persamaan regresi linier sederhana disusun, sebagai berikut : $\mathrm{Z}=$ $2,412+0,403 \mathrm{X}+\mathrm{e}_{\mathrm{i}}$

Makna persamaan regresi linier sederhana sebagai berikut:

1. Konstanta sebesar 2,412 menunjukkan tanpa variabel Kualitas Kehidupan Kerja (X), maka nilai variabel kepuasan kerja $(\mathrm{Y})$ adalah sebesar 2,412.

2. Koefisien regresi variabel Kualitas Kehidupan Kerja (X) sebesar 0,403 menunjukkan bahwa setiap perubahan Kualitas Kehidupan Kerja (X) sebesar satu satuan maka akan mengakibatkan perubahan kepuasan kerja $(\mathrm{Y})$ sebesar 0,403, dengan asumsi variabel lainnya adalah konstan (tetap).

Sedangkan untuk mengetahui seberapa besar pengaruh variabel Kualitas Kehidupan Kerja (X) terhadap Kepuasan Kerja (Z), dapat dilihat hasil analisis Koefisien Determinasi $\left(\mathrm{R}^{2}\right)$ dengan hasil sebagai berikut : 
Tabel 4 : Hasil Pengujian Koefisien Determinasi Kualitas Kehidupan Kerja (X) terhadap Kepuasan Kerja (Z)

Model Summary

\begin{tabular}{|l|r|r|r|r|}
\hline & & & \multicolumn{2}{|c|}{$\begin{array}{c}\text { Adjusted R } \\
\text { Square }\end{array}$} \\
\hline Model & $\mathrm{R}$ & R Square & \multicolumn{2}{c|}{$\begin{array}{c}\text { Std. Error of the } \\
\text { Estimate }\end{array}$} \\
\hline 1 &, $365^{\mathrm{a}}$ &, 134 &, 119 &, 560590 \\
\hline
\end{tabular}

a Predictors: (Constant), Kualitas Kehidupan Kerja (X)

Sumber : Data diolah

Berdasarkan tabel 4 tersebut diperoleh nilai Adjusted R Square $\left(\mathrm{R}^{2}\right)$ sebesar 0,134 artinya 13,4\% variasi Kepuasan Kerja (Z) dipengaruhi Kualitas Kehidupan Kerja (X), sisanya 86,6\% dipengaruhi oleh variabel lainnya yang tidak masuk dalam model ini.

\section{Persamaan III : $\quad \mathbf{Y}=\mathrm{a}_{5}+\mathrm{a}_{6} \mathrm{X}+\mathrm{a}_{7} \mathrm{Z}+\mathrm{e}_{\mathrm{i}}$}

Tabel 5 : Hasil Analisis Regresi Linier berganda antara Quality of Work Life (X) dan Kepuasan kerja $(\mathrm{Z})$ terhadap Kinerja Karyawan $(\mathrm{Y})$

Coefficients(a)

\begin{tabular}{|c|c|c|c|c|c|c|}
\hline \multirow[t]{2}{*}{$\begin{array}{ll}\text { odel } & \text { M } \\
\end{array}$} & & \multicolumn{2}{|c|}{$\begin{array}{l}\text { Unstandardized } \\
\text { Coefficients }\end{array}$} & \multirow{2}{*}{$\begin{array}{r}\begin{array}{r}\text { Standardi } \\
\text { zed Coefficients }\end{array} \\
\text { Beta }\end{array}$} & \multirow[t]{2}{*}{$\mathrm{t}$} & \multirow[t]{2}{*}{ ig. ${ }^{S}$} \\
\hline & & $\mathrm{B}$ & $\begin{array}{l}\text { Std. } \\
\text { Error }\end{array}$ & & & \\
\hline 1 & (Constant) & $\begin{array}{r}- \\
1,295 \\
\end{array}$ &, 555 & & 2,336 & 023 \\
\hline & $\begin{array}{l}\text { Kualitas Kehidupan } \\
\text { Kerja (X) }\end{array}$ & $\begin{array}{r}, 58 \\
7 \\
\end{array}$ & ,141 & ,385 & $\begin{array}{r}4,1 \\
49 \\
\end{array}$ & 000 \\
\hline & Kepuasan Kerja (Z) & $\begin{array}{r}, 73 \\
0\end{array}$ & ,128 &, 528 & $\begin{array}{r}5,6 \\
98\end{array}$ & 000 \\
\hline
\end{tabular}

a Dependent Variable: Kinerja Karyawan (Y)

Sumber : Data diolah

Berdasarkan tabel tersebut persamaan regresi linier sederhana disusun, sebagai berikut: $\mathrm{Y}=-1$, $295+0,587 \mathrm{X}+0,730 \mathrm{Z}+\mathrm{e}_{\mathrm{i}}$

Makna persamaan regresi linier sederhana sebagai berikut :

1. Konstanta sebesar -1,295, menunjukkan bahwa apabila tanpa Kualitas Kehidupan Kerja (X) dan kepuasan kerja (Z) maka nilai Kinerja Karyawan (Y) adalah - 1,295.

2. Koefisien regresi Kualitas Kehidupan Kerja (X) sebesar 0,587 menunjukkan bahwa setiap perubahan Kualitas Kehidupan Kerja (X) sebesar satu satuan maka akan mengakibatkan perubahan kinerja karyawan (Y) sebesar 0,587, dengan asumsi variabel lainnya adalah konstan (tetap).

3. Koefisien regresi Kepuasan Kerja (Z) sebesar 0,730 menunjukkan bahwa setiap perubahan kepuasan kerja (Z) sebesar satu satuan maka akan mengakibatkan peruabahan kinerja karyawan (Y) sebesar 0,730, dengan asumsi variabel lainnya adalah konstan (tetap).

Sedangkan untuk mengetahui seberapa besar pengaruh variabel Kualitas Kehidupan Kerja (X) terhadap Kepuasan Kerja (Z), dapat dilihat hasil analisis Koefisien Determinasi $\left(\mathrm{R}^{2}\right)$ dengan hasil sebagai berikut :

Tabel 6 : Hasil Pengujian Koefisien Determinasi Kualitas Kehidupan Kerja (X), Kepuasan Kerja (Z) terhadap Kinerja Karyawan (Y)

Model Summary

\begin{tabular}{|r|r|r|r|r|}
\hline el & & & Adjusted R & Sod \\
\hline 1 & Square & Std. Error of the Estimate \\
\hline
\end{tabular}


a Predictors: (Constant), Kepuasan Kerja (Z), Kualitas Kehidupan Kerja (X)

Sumber : Data diolah

Berdasarkan tabel 4 tersebut diperoleh nilai Adjusted R Square $\left(\mathrm{R}^{2}\right)$ sebesar 0,576 artinya 57,6\% variasi Kinerja Karyawan (Y) dipengaruhi Kualitas Kehidupan Kerja (X) dan Kepuasan Kerja (Z), sisanya 42,4\% dipengaruhi oleh variabel lainnya yang tidak masuk dalam model ini.

\section{PENGUJIAN HIPOTESIS}

Pengujian hipotesis $\left(\mathrm{H}_{1}, \mathrm{H}_{2}, \mathrm{H}_{3}\right.$, dan $\left.\mathrm{H}_{4}\right)$ dipergunakan uji t. Bilamana nilai sig $<0,05$ maka dinyatakan variabel independent berpengaruh terhadap variabel dependent, dan sebaliknya bilamana nilai sig $>0,05$ maka dinyatakan variabel independent tidak berpengaruh terhadap variabel dependent

\section{Hipotesis 1 :}

Berdasarkan tabel 1 diketahui variabel Kualitas Kehidupan Kerja (X) diperoleh nilai $\mathrm{t}$ hitung $=5,39$ dengan nilai sig sebesar 0,00 sehingga $\mathrm{H}_{1}$ diterima dan $\mathrm{H}_{0}$ ditolak. Dengan demikian disimpulkan bahwa terdapat pengaruh positif dan siginifikan antara variabel kualitas kehidupan kerja $(\mathrm{X})$ terhadap kinerja karyawan $(\mathrm{Y})$.

\section{Hipotesis 2 :}

Berdasarkan tabel 3 diketahui variabel quality of work life $(\mathrm{X})$ diperoleh nilai t hitung $=2,99$ dengan nilai sig sebesar 0,004 sehingga $\mathrm{H}_{2}$ diterima dan $\mathrm{H}_{0}$ ditolak. Dengan demikian disimpulkan bahwa terdapat pengaruh positif dan siginifikan antara variabel kualitas kehidupan kerja (X) terhadap kepuasan Kerja (Z).

\section{Hipotesis 3 :}

Berdasarkan tabel 5 diketahui variabel Kepuasan Kerja $(Z)$ diperoleh nilai t hitung $=$ 5,698 dengan nilai sig sebesar 0,00 sehingga $\mathrm{H}_{3}$ diterima dan $\mathrm{H}_{0}$ ditolak. Dengan demikian disimpulkan bahwa terdapat pengaruh positif dan siginifikan antara variabel Kepuasan Kerja (Z) terhadap Kinerja Karyawan (Y).

\section{Hipotesis 4 : Analisis Jalur}

Berdasarkan tabel 3, pengujian hipotesis model Analisis Jalur pada persamaan ke-2 nilai koefisien regresi sebesar 0,365 dan signifikan pada 0,004 yang berarti Kualitas Kehidupan Kerja (X) berpengaruh positif dan signifikan terhadap Kepuasan Kerja (Z). Nilai koefisien regresi 0,365 merupakan nilai path atau jalur $\left(\mathrm{P}_{2}\right)$.

Berdasarkan tabel 5, pengujian hipotesis model Analisis Jalur pada persamaan ke-3 nilai koefisien regresi Kualitas Kehidupan Kerja (Y) sebesar 0,385 dan signifikan pada 0,000 yang berarti Kualitas Kehidupan Kerja $(\mathrm{Y})$ berpengaruh positif dan signifikan terhadap Kinerja Karyawan $(\mathrm{Y})$. Nilai koefisien regresi 0,385 merupakan nilai path atau jalur $\left(\mathrm{P}_{1}\right)$.

Berdasarkan tabel 5, pengujian hipotesis model Analisis Jalur pada persamaan ke-3 nilai koefisien regresi kepuasan kerja $(Z)$ sebesar 0,528 dan signifikan pada 0,000 yang berarti kepuasan kerja (Z) berpengaruh positif dan signifikan terhadap Kinerja Karyawan (Y). Nilai koefisien regresi 0,528 merupakan nilai path atau jalur $\left(\mathrm{P}_{3}\right)$.

Berdasarkan tabel 4, nilai koefisien $e_{1}$ dapat diperoleh sebagai berikut : $e_{1}=\sqrt{1-R^{2}}=\sqrt{1-0,134}=0,931$.Berdasarkan tabel 6 , nilai koefisien $\mathrm{e}_{2}$ dapat diperoleh sebagai berikut : $e_{2}=\sqrt{1-R^{2}}=\sqrt{1-0,576}=0,651$, Sehingga diagram jalurnya dapat digambarkan sebagai berikut : 


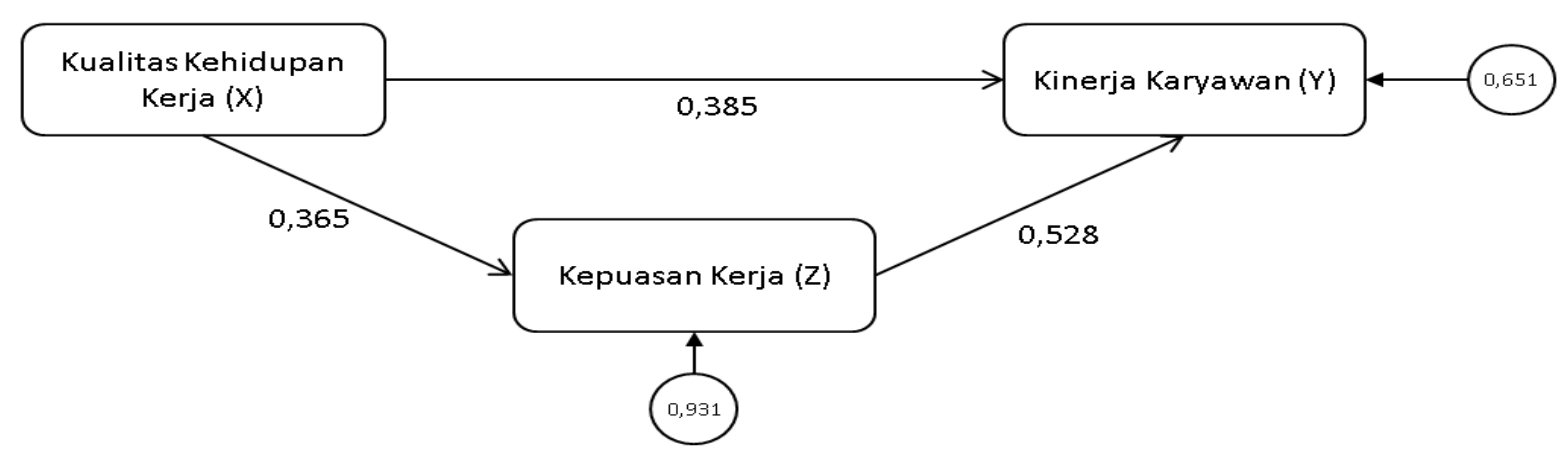

Gambar 3 Model Path Analysis

Berdasarkan model path analysis tersebut dapat dihitung total pengaruh, sebagai berikut:

Pengaruh tidak langsung $(0,365 \times 0,528)=0,193$

Pengaruh langsung $\quad=\underline{0,385}$

Pengaruh total $=\frac{0,578}{0,585}$

Untuk mengetahui apakah variabel mediasi yang berpengaruh sebesar 0,193 atau 19,3\%, berpengaruh signifikan atau tidak, dapat diuji dengan menghitung standar error dari coefficients indirect effect $\left(\mathrm{S}_{\mathrm{p} 2 \mathrm{p} 3}\right)$

$$
\begin{aligned}
& S_{P 2 P 3}=\sqrt{P_{3}{ }^{2} \cdot S_{P 2}{ }^{2}+{P_{2}}^{2} \cdot S_{P 3}{ }^{2}+S_{P 2}{ }^{2} S_{P 3}{ }^{2}} \\
& S_{P 2 P 3}=\sqrt{0,528^{2} \cdot 0,135^{2}+0,365^{2} \cdot 0,128^{2}+0,135^{2} 0,128^{2}} \\
& S_{P 2 P 3}=0,08
\end{aligned}
$$

berikut :

Berdasarkan hasil $\mathrm{S}_{\mathrm{p} 2 \mathrm{p} 3}$, maka dapat dihitung nilai $\mathrm{t}_{\text {hitung }}$ dari pengaruh mediasi sebagai

$t_{\text {hitung }}=\frac{P_{2} P_{3}}{S_{P 2 P 3}}=\frac{0,193}{0,08}=2,41$

Berdasarkan perhitungan tersebut dapat disimpulkan bahwa variabel mediasi yang berpengaruh sebesar 19,3\% tersebut berpengaruh signifikan. Hal tersebut ditunjukkan nilai $\mathrm{t}_{\text {hitung }}$ $=2,41$ lebih besar dari $\mathrm{t}_{\text {tabel }(5 \% ; 57)}=2,003$.

Berdasarkan perhitungan tersebut maka $\mathrm{H}_{4}$ diterima dan $\mathrm{H}_{0}$ ditolak. Yang berarti bahwa Kepuasan Kerja ( $\mathrm{Z}$ ) memediasi hubungan antara Kualitas kehidupan kerja (X) terhadap Kinerja Karyawan (Y).

\section{IMPLEMENTASI PENELITIAN}

Berdasarkan hasil penelitian dan pembahasan yang telah dikemukakan di atas, implikasi dari hasil penelitaian adalah sebagai berikut :

a. Kualitas Kehidupan Kerja (X) berpengaruh signifikan terhadap Kinerja Karyawan (Y) pada karyawan bagian T.U.K PG. Kebon Agung Malang, dibuktikan dengan nilai t hitung = 5,391 $>\mathrm{t}$ tabel $=1,673$ dan nilai $\mathrm{p}$-value $=0,000<0,05$. Dari koefisien determinasi $\left(\mathrm{R}^{2}\right)$ sebesar 0,322 menunjukkan bahwa Kualitas Kehidupan Kerja (X) berpengaruh sebesar 32,2\% terhadap Kinerja Karyawan (Y), sedangkan sisanya sebesar 67,8\% dipengaruhi variabel lainnya. Penelitian ini mendukung penelitian yang telah dilakukan oleh Normala, (2010), Husnawati, (2006), Bekti, (2018), dan Sudiq, (2020), yang menyatakan bahwa Kualitas Kehidupan Kerja (X) berpengaruh terhadap Kinerja Karyawan (Y). 
b. Kualitas Kehidupan Kerja (X) berpengaruh signifikan terhadap Kepuasan Kerja (Z) pada karyawan bagian T.U.K PG. Kebon Agung Malang, dibuktikan dengan nilai t hitung $=2,990$ $>\mathrm{t}$ tabel $=1,673$ dan nilai $\mathrm{p}$-value $=0,004<0,05$. Dari koefisien determinasi $\left(\mathrm{R}^{2}\right)$ sebesar 0,119 menunjukkan bahwa Kualitas Kehidupan Kerja (X) berpengaruh sebesar 11,9 \% terhadap Kepuasan Kerja (Z), sedangkan sisanya sebesar 88,1\% dipengaruhi variabel lainnya. Hal ini mendukung penelitian yang dilakukan oleh Husnawati, (2006), Lusri, (2017) dan (Tobing, 2009) yang menyatakan bahwa kepuasan kerja dapat meningkatkan kinerja karyawan

c. Kepuasan Kerja (Z) berpengaruh signifikan terhadap Kinerja Karyawan (Y) pada karyawan bagian T.U.K PG. Kebon Agung Malang, dibuktikan dengan nilai t hitung $=2,990>\mathrm{t}$ tabel $=1,673$ dan nilai $\mathrm{p}$-value $=0,004<0,05$. Dari koefisien determinasi $\left(\mathrm{R}^{2}\right)$ sebesar 0,119 menunjukkan bahwa Kepuasan Kerja $(Z)$ berpengaruh sebesar 11,9 \% terhadap Kinerja Karyawan (Y), sedangkan sisanya sebesar 88,1\% dipengaruhi variabel lainnya. Hal ini mendukung penelitian yang dilakukan oleh Husnawati, (2006), Lusri, (2017) dan (Tobing, 2009) yang menyatakan bahwa kepuasan kerja dapat meningkatkan kinerja karyawan

d. Kualitas Kehidupan Kerja (X) berpengaruh signifikan terhadap Kinerja Karyawan (Y) dengan Kepuasan Kerja (Z) sebagai variabel intervening pada karyawan bagian T.U.K PG. Kebon Agung Malang, dibuktikan dari nilai $\mathrm{F}$ hitung $=38,644>\mathrm{F}$ tabel $=2,766$ dan nilai $\mathrm{p}-$ value $=0,000<0,05$. Dari koefisien determinasi $\left(R^{2}\right)$ sebesar 0,561 menunjukkan bahwa $56,1 \%$ variasi kinerja karyawan dipengaruhi variabel quality of work life dan kepuasan kerja sedangkan sisanya $43,9 \%$ dipengaruhi oleh variabel lainnya. Sedangkan dengan path analysis diketahui nilai $\mathrm{t}$ hitung $=2,41>\mathrm{t}$ tabel $=2,003$ dengan tingkat signifikansi 0,05, maka dapat disimpulkan bahwa koefisien mediasi 0,193 signifikan yang berarti ada pengaruh mediasi 19,3\%. Hal ini mendukung penelitian yang telah dilakukan oleh Husnawati, (2006) dalam penelitian menemukan bahwa kepuasan kerja memediasi pengaruh tidak langsung antara kualitas kehidupan kerja terhadap kinerja karyawan pada Perum Pegadian Kanwil VI Semarang

\section{KESIMPULAN}

Berdasarkan hasil penelitian dan pembahasan, dapat ditarik simpulan sebagai berikut:

1. Kualitas Kehidupan Kerja (X) berpengaruh signifikan terhadap Kinerja Karyawan (Y) pada karyawan bagian T.U.K PG. Kebon Agung Malang.

2. Kualitas Kehidupan Kerja (X) berpengaruh signifikan terhadap Kepuasan Kerja (Z) pada karyawan bagian T.U.K PG. Kebon Agung Malang.

3. Kepuasan Kerja ( $\mathrm{Z}$ ) berpengaruh signifikan terhadap Kinerja Karyawan (Y) pada karyawan bagian T.U.K PG. Kebon Agung Malang.

4. Kualitas Kehidupan Kerja (X) berpengaruh signifikan terhadap Kinerja Karyawan (Y) dengan Kepuasan Kerja (Z) sebagai variabel intervening pada karyawan bagian T.U.K PG. Kebon Agung Malang

\section{REFERENSI}

Bekti, R. R. (2018). Pengaruh Kualitas Kehidupan Kerja terhadap Kepuasan Kerja Karyawan Rumah Sakit Ibu dan Anak X Surabaya. Jurnal Administrasi Kesehatan Indonesia, 6(2), 156 163. https://doi.org/10.20473/jaki.v6i2.2018.156-163

Bernadin, H. J., \& Russel, n J. E. A. (2003). Human resource management (An Experimental Approach International Edition). Mc. Graw-Hill Inc. 
Cascio, W. F. (2010). Managing Human Resources: Productivity, Quality of WorkLife (Eighth Edition). McGraw Hill Companies, Inc. https://pdfs.semanticscholar.org/05da/d8dc13d3b16932070ee01a6654f82540355d.pdf

Dessler, G. (2006). Manajemen Sumber Daya Manusia (Jilid 1). PT. Indeks.

Ghozali, I. (2011). Aplikasi Analisis Multivariate dengan Program IBM SPSS 19. BP Universitas Diponegoro.

Hadari, N. (2008). Manajemen Sumber Daya Manusia. Gajah Mada University Press.

Hadiwijaya, H. (2016). Pengaruh Quality Of Work Life Terhadap Person Organization Fit Dan Implikasinya Pada Kinerja Karyawan. Jurnal Manajemen Dan Bisnis Sriwijaya, 14(4), 439_ 448. https://doi.org/10.29259/jmbs.v14i4.4511

Handoko, T. H. (2012). Manajemen Personalia dan Sumberdaya Manusia (kedua). BPFE Yogyakarta.

Hasibuan, M. S. P. (2013). Manajemen Sumber Daya Manusia. PT. Bumi Aksara.

Husnawati, A. (2006). Analisis Pengaruh Kualitas Kehidupan Kerja Terhadap Kinerja Karyawan Dengan Komitmen Dan Kepuasan Kerja Sebagai Intervening Variabel (Studi Pada PERUM Pegadaian Kanwil VI Semarang) [Masters, Program Pascasarjana Universitas Diponegoro]. http://eprints.undip.ac.id/15378/

Kurniawati, C. E. (2018). Pengaruh Quality Of Work Life Terhadap Work Engagement Dan Organizational Citizenship Behaviour Pada Perusahaan Elektronik Di Surabaya. Agora, 6(2), Article $2 . \quad$ http://publication.petra.ac.id/index.php/manajemenbisnis/article/view/7714

Lusri, L. (2017). Pengaruh Motivasi Kerja Terhadap Kinerja Karyawan Melalui Kepuasan Kerja Sebagai Variabel Mediasi Pada Karyawan Pt. Borwita Citra Prima Surabaya. Agora, 5(1), Article 1. http://publication.petra.ac.id/index.php/manajemen-bisnis/article/view/5259 Mankunegara. (2002). Manajemen Sumber Daya Manusia Perusabaan. PT Remaja Rosdakarya.

Mousavi, S. H., Monfared, S. Y., \& Heidary, A. (2011). Investigating The Relationship Between Life Quality And Productivity In Physical Education Office Employees In Zanjan Province. Procedia - Social and Behavioral Sciences, 15, 3665-3668. https://doi.org/10.1016/j.sbspro.2011.04.354

Normala, D. (2010). Investigating the Relationship between Quality of Work Life and Organizational Commitment amongst Employees in Malaysian Firms. International Journal of Business and Management, 5(10), p75. https://doi.org/10.5539/ijbm.v5n10p75

Robbins, S. P. (2008). Perilaku Organisasi organizational Behavior (12th ed.). Salemba Empat.

Sudiq, R. A. S. D. (2020). Pengaruh Kualitas Kehidupan Kerja terhadap Komitmen Organisasi melalui Kepuasan Kerja pada PT. Segar Murni Utama. Jurnal Ilmu Manajemen, 8(3), $921-$ 930. https://doi.org/10.26740/jim.v8n3.p921-930

Sugiyono. (2012). Metode Penelitian Kuantitatif Kualitatif dan R \& D. ALFABETA - Bandung.

Timpe, A. D. (2002). Seri Ilmu dan Seni Manajemen Bisnis "Kinerja." Gramedia Asri Media.

Tobing, D. S. K. L. (2009). Pengaruh Komitmen Organisasional dan Kepuasan Kerja Terhadap Kinerja Karyawan PT. Perkebunan Nusantara III di Sumatera Utara. Jurnal Manajemen Dan Kewirausahaan, 11(1), 31-37. https://doi.org/10.9744/jmk.11.1.pp

Walton RE. (1973). Qwl indicators, prospects and problems. Canada Department Of Labour. https://doi.org/10.22146/ae.31491

Wibowo, S. A. (2017). Pengaruh Quality Of Work Life (Qwl) Dan Motivasi Terhadap Kinerja Pegawai Kecamatan Di Kabupaten Kulonprogo D.I Yogyakarta. JBTI : Jurnal Bisnis : Teori Dan Implementasi, 8(1), 84-96. https://doi.org/10.18196/bti.81085 